\title{
THOROUGHLY GRASPING THE UNION BETWEEN THE SCIENCE AND REVOLUTION OF DIALECTICAL MATERIALISM FOR STUDENTS OF PEOPLE'S PUBLIC SECURITY SCHOOLS
}

\author{
Dang Thi Thuy Hoa \\ The People's University of Police
}

\begin{abstract}
Dialectical materialism is the unity of science and revolution. Accordingly, the higher the scientific feature of the dialectical materialism, the more radical and profound the revolution of the doctrine; the more revolutionary that the dialectic materialism is shown, the more the theory will continue to supplement, develop, truly reflect in a right, objective and scientific way about the movement and development of the world. Students of People's Public Police schools are required to acquire and be imbued with dialectical materialism in its scientific and revolutionary nature. Based on dialectical materialism, analytical method and synthesized method, the author focused on clarifying the unity of science and revolution of dialectical materialism. Thereby, the author proposes some basic solutions so that officers and lecturers of People's Public Security implement orientations to foster dialectical materialism to create the foundation of world outlook and methodology of People's Police students.
\end{abstract}

Keywords: People's Public Security; students; dialectical materialism; science; revolution.

Received: 15/01/2020; Revised: 28/02/2020; Published: 17/3/2020

\section{QUÁN TRIẸT SỰ THỐNG NHẤT GIŨ̉A TÍNH KHOA HỌC VÂ TÍNH CÁCH MẠNG CỦA PHÉP BIỂN CHÚNG DUY VẠT CHO HỌC VIÊN CÁC TRƯỜNG CỐNG AN NHÂN DÂN}

\author{
Đặng Thị Thúy Hoa \\ Trường Đại học Cảnh sát nhân dân
}

TÓM TẮT

Phép biện chứng duy vật mang trong mình sự thống nhất của tính khoa học và tính cách mạng. Theo đó, tính khoa học của phép biện chứng duy vật càng cao thì tính cách mạng của học thuyết càng triệt để, sâu sắc; tính cách mạng của phép biện chứng duy vật càng được thể hiện thì càng giúp cho học thuyết được tiếp tục bổ sung, phát triển, thực sự phản ánh một cách đúng đắn, khách quan, khoa học sự vận động, phát triển của thế giới. Đối với học viên các trường Công an nhân dân đòi hỏi phải tiếp thu và thấm nhuần phép biện chứng duy vật, trước hết ở tính khoa học và tính cách mạng của nó. Vận dụng phương pháp luận duy vật biện chứng, phương pháp phân tích, tổng hợp, tác giả đi sâu làm rõ sự thống nhất của tính khoa học và tính cách mạng trong phép biện chứng duy vật. Qua đó, tác giả đề xuất một số giải pháp để cán bộ, giảng viên các trường Công an nhân dân từng bước thực hiện các định hướng nhằm bồi dưỡng phép biện chứng duy vật, tạo cơ sở hình thành nền tảng thế giới quan, phương pháp luận của học viên Công an nhân dân.

Từ khóa: Công an nhân dân; học viên; phép biện chưng duy vật; khoa học; cách mạng.

Ngày nhận bài: 15/01/2020; Ngày hoàn thiện: 28/02/2020; Ngày đăng: 17/3/2020

Email: tthuyhoa1972@gmail.com

DOI: $\underline{\text { https://doi.org/10.34238/tnu-jst.2020.03.2548 }}$ 


\section{Introduction}

According to Lenin, dialectical materialism can be considered to be the living soul of Marxism. For that reason, dialectical materialism is the core of philosophy and one of the foundations of Marxism. Based on the outline of the laws of mobilization and objective development of the world, nature, society and human thought, dialectical materialism has become the theoretical weapon of the proletariat in the revolutionary struggle to build socialism and communism for the future of mankind. The dialectical materialism contains the unity of science and revolution and also it is the foundation of science and revolution of Marxism - Leninism in general.

There have been domestic and international studies related to the topic of the article, typically works such as The dialectic history series [1], The scientific and revolutionary nature of Marxism - Leninism [2], the article "Science and revolution of Marxism and the meaning of the era and the article" [3], "The unity between scientific nature and revolution is the characteristic of Marxism" [4]. In general, those works mention the unity between the science and revolution of Marxism - Leninism in general in terms of philosophy, political economy, scientific socialism. However, the unity between the revolution and the science of material dialectical materialism, which is a living soul of Marxism - Leninism, is not specifically mentioned nor analyzed and clarified as typical characteristics. Therefore, it is necessary to clarify the unity between the science and the revolution of dialectical materialism to give us a deeper understanding of one of the foundations of Marxist - Leninism.

Students of People's Police Schools - future People's Police soldiers whose mission is to protect the socialist political regime, protect the nation's independence, peace and happiness for the people, need to acquire and be imbued with dialectic materialism, especially its science and revolution.

\section{The unity between the science and revolution of an dialectic materialism}

Dialectical materialism is built by Marx and Engels after a research process of poring over the quintessence of ideology of mankind and the process of practicing world revolution; supplemented and developed by Lenin, President Ho Chi Minh, and many typical revolutionaries in accordance with the era and the situation of revolution. The Dialectical materialism in the system of Marxist Leninist theory is the core of theoretical nucleus, the basis of the world outlook and methodology. As the world outlook, the methodology of Marxism - Leninism, the science, the revolution of dialectical materialism determines the science and revolution of Marxism - Leninism.

The science of dialectical materialism in particular, the systems of reasoning in general is that it is possible to generalize the objective rules of movement of the world. Dialectical materialism is established by Marxist Leninist founders of on the basis of research, it transcends the quality of dialectical theories and ideas existing in the history of human thought (especially is the classical dialectical materialism of Germany). For dialectical materialism, the science is reflected by objectively and accurately drawing out the rules of movement of society, nature, thought, etc. and at the same time it is tested in reality. The Dialectical materialism is truly a scientific theory. This was once emphasized by the Marxist - Leninist founders, such as Engels commented, "Dialectics [...] is the science of the common rules of movement and the development of nature, human society and thought" [5; p. 201]; Lenin said, "[...] dialectics is the doctrine of development which in its most perfects, profoundest and is 
not a superficial form; the doctrine of the relativity of human's cognition, this perception reflects that the material always grows constantly" [6; p. 53], etc.

The revolution of dialectical materialism is reflected by examining things that exist in the constant movement, development, and transformation. The method of dialectical materialism with that revolutionary way of thinking gave the revolutionary masses and especially the proletariat a sharp weapon in recognizing and improving the world. Besides, the revolution of dialectical materialism is the revolutionary critique of the doctrine. That is the criticism and the requirement of radical social reform, the negation of the old society, the construction of nice commune for humans. The dialectical materialism in particular, Marxism Leninism, in general, is a theoretical weapon of the working class in the revolutionary struggle to overthrow capitalism, successfully build socialism and communism. Thus, it should be profoundly and radically revolutionary. Moreover, dialectical materialism is the basis for promoting active revolutionary thinking and action of human beings, emphasizing subjective factors in addition to objective factors in order to successfully achieve its goals.

The unity between revolutionary and scientific in the dialectical materialism is shown in the following contents:

\section{The higher the scientific of the dialectical materialism, the more radical and profound the revolution of the doctrine}

Dialectical materialism is firstly a science, the unity of dialectical materialist world outlook, and dialectical materialism methodology. It is a tool for people to recognize the world, human society, human thinking, etc.; it is a subjective dialectic which reflected objective dialectic. Dialectical materialism aims to provide the human with scientific aspects to explain the movement of the world and become a tool to perceive and improve the world of man. Therefore, the righteous generalization of the world's dialectic provides the objective rules of nature, society, and methodology under the perspective that helps people influence the world properly, completely and continuously; it is a scientific tool for people to improve their world revolution.

In the natural aspect, dialectical materialism is closely linked with natural science, constantly captures and generalizes achievements in natural science to supplement, develop and perfect dialectical materialism science. And it is also through the continuous improvement of its scientific conclusions that dialectical materialism plays a great role in not only perspective of the world outlook but also the methodology for people to recognize and improve the natural world properly. The dialectical materialism understanding of nature brings strength to the people in reforming the natural world revolution to serve the human.

In the social aspect, dialectical materialism becomes the weapon of scientific reason and revolution of the class (the working class) plays a leading role in the revolution of the new era. Through the act of acquiring and be imbued with the dialectical materialism, the working class understood the constituent parts of Marxism - Leninism and take them as a foundation for awareness and improvement of the world in a solid revolutionary position. In particular, the dialectical materialism applied by the Marxist-Leninist founders tin the scientific and revolutionary research of the history of human society has drawn the objective rules of mobilization of human society; at the same time, these objective rules are placed beside the subjective factors of human activity, the Marxist - Leninist founders emphasize the dialectical unity between the subjective and the objective 
factors and emphasized the revolutionary stance, initiative, and creativity in fulfilling the historic mission of the working class in the new era, etc.

In short, the more comprehensive the natural, social, thinking, and scientific aspects of dialectical materialism, the more radical and profound the revolution of the doctrine. The more human reflects the rules exactly, the more the purpose, the way, the methods of impact can be identified effectively.

The more revolutionary the dialectic materialism is expressed, the more it helps the theory to continue to supplement, develop, and reflect properly, objectively, and scientifically the movement and development of the world

The Marxist-Leninist doctrine, from its inception, has become a material weapon by being spread into the labor class movement against the bourgeois reactionary forces. At the same time, because of being relied on and tested by the revolutionary practices of the proletariat, dialectical materialism has a strong connection between science and revolution.

Marx once affirmed that philosophy should not be used to explain the world, but to improve the world. That is the purpose of dialectical materialism and Marxist Leninism was. The more revolutionary the dialectic materialism (or the main point is the continuous advancement of the process of improving the old society and the building of a better new society), the more embodied the Marxist - Leninist theory and it will be continued to supplement, develop, truly reflect, objectively, scientific movement and development of the world. In an era where the bourgeoisie had lost its revolution, the working class (the proletariat class) was the class without science constraints, from natural sciences to communal sciences, they do not turn science into a tool of dominance of their class, but constantly searching, discovering and fully and objectively drawing out the rules of the world. The dialectic materialism with its class base is the working class, which is the more they demonstrate the full revolution, the more the science of the doctrine is enhanced.

In short, the more scientific of dialectical materialism, the more radical and profound the revolution of the doctrine; the more revolutionary the dialectic materialism is shown, the more the theory will continue to supplement, develop, truly reflect in a right, objective and scientific way of the movement and development of the world. In dialectical materialism, science and revolution' existence is cemented.

3. The unity between science and the revolutionary of a dialectic materialism some issues need to be considered for students of people's police schools

Dialectical materialism is one of the foundations and cores of the world outlook which is essential for everyone. For the People's Public Security Forces, to be imbued with dialectical materialism in particular, Marxism - Leninism, in general, provide for the officers and soldiers of the People's Public Security world outlook and scientific methodology to be the basis for proper awareness and revolutionary action.

At the People's Police schools, dialectical materialism firstly transmitted to the police students mainly through the module of Basic Principles of Marxism - Leninism, the political theory modules and be instructed to continue studying and applying in subjects, practical sessions and internships during study time. Police students can learn about the position, the role and the importance of study in order to be imbued with dialectical materialism, thereby fostering the world outlook and scientific methodology which can be used for researching, developing and applying the people's police science in their 
work to serve the Party, the country and the people in the most effective way.

In the coming time, in order to thoroughly grasp the unity between the revolution and the science of dialectical materialism for Police students, it is possible to study and apply these following orientations:

Firstly, raising the awareness of the People's Police officers, lecturers and students about the importance of mastering the science and revolution of dialectical materialism.

Dialectical materialism in particular, Marxist - Leninism, in general, is truly a scientific theory of mankind, is a guide for us to fully and closely approach the rules of motion of nature, society, and mindset. Therefore, the Party Committee of the Presidential Board, the leaders at all levels should thoroughly grasp the profound research, raise the awareness of officials and lecturers, of the students of People's Police Schools about the importance of mastering the science and revolution of dialectical materialism (and Marxist - Leninism in general). The act of raising awareness among cadres and lecturers is the first requirement that is required to teach and improve students' understanding of this important content. Only when police students understand the necessity and the correctness of mastering dialectical materialism, can they set in students' thoughts about the content of dialectical materialism, make it into a world outlook kernel, methodology of awareness and action.

Secondly, officials and lecturers of People's Police Schools must constantly follow the reality and summarize the practice to enrich the theory of dialectical materialism.

In the process of researching and applying dialectical materialism, officials and lecturers of People's Police Schools must always pay attention to the instructions of Marxist Leninist founders that the Marxist - Leninist doctrine is not complete and completed things but must always be supplemented and developed followed by the movement and relentless changes of the world; must understand the vitality of dialectical materialism of Marxist - Leninist theory in the new age. In particular, today's era has marked the great changes with the strong development of the fourth industrial revolution, science and technology have made great progress; the world pays much attention to the information society and the knowledge economy; the process of globalization is strongly developing, etc. There are more rapid changes than the previous era which require constant research, summarize the practice to improve theories on dialectical materialism it is the spirit of Marxist-Leninist founders who instructs the next generations and is also the spirit in applying dialectical materialism methodology itself to the study of dialectics materialism.

Thirdly, police students need to be fostered and built up the proletariat stance and always respect the people.

To be able to absorb and manipulate the dialectical materialism, it requires that we have to be imbued with its science and revolution. Only by practicing and step by step standing on the position of the proletariat, can the police students acquire and effectively use dialectical materialism in their awareness and practical actions to protect the Party, the country, the people, the goal of national independence and socialism, etc. Besides, the police students must be taught to respect the people and consider the task of ensuring the peaceful life of the people to be their life. In order to achieve this requirement, beside study time, the police students should have a chance to participate in practical meetings with the people, such as to eat, live, work with and help the people; to meet and exchange with officials and soldiers with practical work, the one who has good ideas and ways to help them fulfill their tasks and bringing the people's faith in the Party, 
the country and the People's Public Security, etc. by doing these things, officers and lecturers of the People's Police forces set out the goals and requirements of the class stance, the political consciousness which need to be achieved, then formulate clear, detail and attractive plans for students to meet the requirements, etc.

\section{Conclusions}

As the core and foundation of the philosophy of Marxist - Leninist theory, dialectical materialism demonstrates the unity between profound science and revolution. Accordingly, the higher the scientific feature of the dialectical materialism, the more radical and profound the revolution of the doctrine; the more revolutionary that the dialectic materialism is shown, the more the theory will continue to supplement, develop, truly reflect in a right, objective and scientific way about the movement and development of the world. To be imbued with the unity between the scientific and revolutionary nature of dialectical materialism, officials and lecturers of the People's Police Schools should pay attention and step by step implement orientations to foster dialectical materialism. The world outlook and methodology of police students such as raising the awareness of People's Public Security officers, lecturers, and students about the importance of mastering the science and revolution of dialectical materialism; cadres and lecturers of People's Police Schools must constantly keep abreast of reality, summarize reality to enrich the theory of dialectical materialism; police students need to be fostered and formulated on the proletariat' stance and having respect to the people.

\section{REFERENCES}

[1]. Institute of Philosophy - Academy of Sciences of the USSR, The dialectic history, vol. I-VI, Ha Noi: The National Political Publishing House (in Vietnamese), 1998.

[2]. C. B. Hoang, The scientific and revolutionary nature of Marxism - Leninism, Ha Noi: The National Political Publishing House (in Vietnamese), 2008.

[3]. H. N. Le, "Science and revolution of Marxism and the meaning of the era," (in Vietnamese), Political Theory Journal, vol. 5, pp. 10-15, 2018.

[4]. Q.T. Lam, "The unity between scientific nature and revolution is the characteristic of Marxism," (in Vietnamese), Political Theory Journal, vol. 7, pp. 17-17, 2015.

[5]. Marx and Engels Collected Works, vol. 20, Ha Noi: The National Political Publishing House (in Vietnamese), 1995.

[6]. V.I. Lenin Collected Works, vol. 23, Moskva: The Progress Publishers, 1980. 